\title{
Cold Dry Air Provocation and Immunoglobulin E in Nasal Fluid for Diagnosing Nonspecific Hyper-Reactivity
}

\author{
Young-Joo Ko, Yoon-Gi Choi, Tae-Suk Kyung, Dae-Young Kim, \\ Jun-Ha Hwang, Tae Young Jang, and Young Hyo Kim \\ Department of Otorhinolaryngology, Inha University College of Medicine, Incheon, Korea
}

\author{
비특이적 과반응성 평가를 위한 저온저습공기 유발검사 및 비즙 내 면역글로불린 $\mathrm{E}$ 분석의 유용성 \\ 고영주 · 최윤기 · 경태석 · 김대영 · 황준하 · 장태영 · 김영효 \\ 인하대학교 의과대학 이비인후과학교실
}

Received August 17, 2016

Revised October 17, 2016

Accepted October 18, 2016 Address for correspondence Young Hyo Kim, MD, PhD Department of Otorhinolaryngology, Inha University College of Medicine, 27 Inhang-ro, Jung-gu, Incheon 22332, Korea

Tel $+82-32-890-2437$

Fax $+82-32-890-3580$

E-mail inhaorl@inha.ac.kr
Background and Objectives We aimed to evaluate the usefulness of cold dry air (CDA) provocation test in patients with non-allergic or allergic rhinitis.

Subjects and Method Twenty-one patients (13 males and 8 females, mean age $36.9 \pm 17.6$ years) with symptoms of rhinitis were enrolled. We classified patients into groups A (control group, $n=9$ ) and $B$ (allergic group, $n=12$ ) according to their skin prick test results. Before and after $\mathrm{CDA}$ provocation $\left(0^{\circ} \mathrm{C}\right.$, relative humidity $<10 \%$, total 400 liters during 6 minutes), we evaluated changes in nasal symptoms. We collected serum, and nasal fluid before and after CDA provocation using the filter paper method. We measured serum and nasal fluid IgE levels, compared them between the groups, and evaluated the correlation between serum and nasal fluid IgE.

Results After the CDA provocation, group B had more aggravation of symptoms than group A, with a statistical significance (for nasal obstruction, group A: $3.0 \pm 2.4$, group B: $5.8 \pm$ $3.4, p=0.049$; for itching, group A: $1.0 \pm 1.6$, group B: $3.8 \pm 3.4, p=0.045$ ). The level of serum total IgE was significantly higher in group B (group A: $152.7 \pm 67.3 \mathrm{ng} / \mathrm{mL}$, group B: $612.1 \pm 291.4$ $\mathrm{ng} / \mathrm{mL}, p=0.001)$. The titer of nasal fluid IgE was higher in group B, before and after the CDA challenge (before CDA, group A: $91.7 \pm 52.6 \mathrm{ng} / \mathrm{mL}$, group B: $810.0 \pm 1042.3 \mathrm{ng} / \mathrm{mL}, p=0.029$, after CDA, group A: $55.8 \pm 43.8 \mathrm{ng} / \mathrm{mL}$, group B: $354.9 \pm 236.7 \mathrm{ng} / \mathrm{mL}, p=0.003$ ). There was a significant correlation between the serum IgE and nasal fluid IgE levels after the CDA provocation test $\left(\mathrm{R}^{2}=0.749, p<0.001\right)$.

Conclusion The CDA provocation test and measurement of nasal fluid IgE level could be useful for the evaluation of nonspecific hyper-reactivity.

Korean J Otorhinolaryngol-Head Neck Surg 2017;60(1):19-23

Key Words Allergic rhinitis $\cdot$ Immunoglobulin E - Nasal provocation tests.
서 론

'비특이적 과반응성(nonspecific hyper-reactivity)'이란, 알레르기 혹은 비(非) 알레르기 비염 환자에서 항원성이 없 는 비특이적 자극(갑작스러운 온도변화, 담배 연기, 향수 등) 에 의해 코막힘, 콧물, 재채기 등 전형적인 비염 증상이 악화 되는 현상을 말한다. ${ }^{1)}$ 이러한 비특이적 과반응성을 진단하기
위해 "비특이적 비강유발검사(nonspecific nasal provocation test)'를 시행할 수 있다. ${ }^{2}$ 비특이적 비강유발검사의 종류는 크게 두 가지로 분류되는데, 주로 약물(히스타민, 메타콜린 등)을 사용하는 직접적 유발검사 및 비특이적 자극(만니톨, 증류수, 캡사이신 등)을 사용하는 간접적 유발검사가 그것이 다. 이 중 저온저습공기 유발검사(cold dry air provocation test)는 간접적 유발검사에 해당한다. ${ }^{2)}$ Braat 등 ${ }^{3)}$ 의 연구자들 
은, 비알레르기성, 비감염성 비염(non-allergic, non-infectious rhinitis) 환자에서 비특이적 과반응성을 진단하는 데 있어 저온저습공기 자극이 히스타민에 비해 높은 특이도를 갖는 다고 보고하였다. 본 연구진 역시 선행연구를 통하여, 저온저 습공기 유발검사가 비특이적 과반응성의 진단에 유용함을

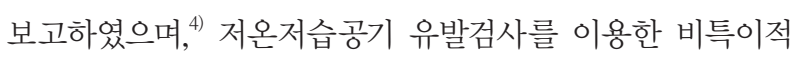
과반응성의 진단기준을 제시하기도 하였고, ${ }^{5)}$ 외래에서 간단 하게 시행할 수 있으면서도 실제 유발검사 결과와 잘 부합하 는 비특이적 과반응성 설문지를 개발하기도 하였다. ${ }^{6}$

면역글로불린 $\mathrm{E}$ 는 알레르기 반응에 있어 중요한 역할을 담당하는 항체이다. 하지만 지금까지 저온저습공기 자극검사 전후, 비즙 내 면역글로불린 $\mathrm{E}$ 의 변화를 평가한 연구는 없었 던 실정이다. 비염 환자에서 전신적 감작 여부를 알아보기 위 해서는 혈청 내 면역글로불린 $\mathrm{E}$ 농도가 도움이 되나, 비강 내 알레르기 염증반응과 관련한 정보를 얻기 위해 비즙 내 면역 글로불린 $\mathrm{E}$ 에 대한 평가가 필요하다. 따라서, 본 연구에서는 먼저 1) 저온저습공기 유발검사의 유효성을 평가하기 위해 유발검사 전후 증상의 변화를 평가하고, 2) 혈청 내, 그리고 유 발검사 전후 비즙 내 면역글로불린 $\mathrm{E}$ 의 농도를 측정하고, 3) 혈청 및 비즙 내 면역글로불린 $\mathrm{E}$ 사이의 연관관계를 분석함 으로써, 저온저습공기 유발검사 및 비즙 내 면역글로불린 $\mathrm{E}$ 분석의 임상적 유용성을 평가하고자 하였다.

\section{대상 및 방법}

\section{환자군 및 대조군}

적어도 1 년 이상의 지속적인 비염 증상을 주소로 내원한 21 명의 환자(남자 13 명, 여자 8명, 평균 연령 $36.9 \pm 17.6$ 세)를 대상으로 하였다. 모든 환자에서 피부단자검사(skin prick test) 를 시행하였으며, 모든 항원에 대해 음성인 환자를 group A(대 조군, $n=9$ ), 적어도 하나 이상의 항원에 대해 강양성(양성대조 액 히스타민과 비교하였을 때 팽진의 크기가 같거나 클 경우) 인 환자를 group $\mathrm{B}$ (알레르기비염 환자군, $\mathrm{n}=12$ )로 정의하였 다. 1 개월 이내 비강 내 혹은 전신성 스테로이드를 사용하였 거나 중단할 수 없는 환자, 항히스타민제 또는 류코트리엔 수 용체 길항제 등의 약물을 1 주일 이내 사용하였거나 중단할 수 없는 환자, 조절되지 않는 전신성 질환이 있거나 비강 내 수술을 3 개월 이내 시행받은 환자, 만성 부비동염 혹은 비용 종 등의 질환이 비내시경 혹은 전산화단층촬영 등으로 확인 된 환자, 임산부 및 수유부 등은 연구 대상에서 제외하였다. 본 연구는 인하대학교병원 임상시험심사위원회(No. 2014-02005)의 승인을 받은 후 이루어졌으며, 환자들은 연구 목적 및 방법에 대한 설명을 충분히 들은 후 자발적으로 연구에
참여하였다.

\section{저온저습공기 유발검사(Cold dry air provocation test) 및 비즙 채취}

환자는 실내온도 $\left(20^{\circ} \mathrm{C}\right)$ 에서 적어도 15 분 이상 안정된 상태 로 대기하였다. 저온저습공기 자극 전 비강 내에 남아 있는 비 즙을 제거하기 위해 가볍게 코를 풀도록 하였고, 이후 따뜻하 게 가열한 생리식염수 $5 \mathrm{~mL}$ 정도를 이용하여 가볍게 비강 세 척을 시행하였다. 이들 조치로 인한 자극의 영향이 사라질 수 있도록 15 분 정도 추가로 대기한 후 검사를 진행하였다.

저온저습공기 유발검사를 시행하기 위해, 의료용 공기를 냉 각기(refrigerator)에 통과시켜 $0^{\circ} \mathrm{C}$ 내외로 냉각하였다. 이후 습 기제거필터(mist separator)에 공기를 통과시켜 상대습도를 $10 \%$ 이하로 낮추었고, 일정한 압력 및 생물학적 안전성을 위 해 압력조절기(pressure regulator) 및 필터를 사용하였다. 이 렇게 하여 제조된 온도 $0^{\circ} \mathrm{C}$, 상대습도 $10 \%$ 이하의 저온저습공 기를 소아용 양압마스크(pediatric continuous positive airway pressure mask)를 이용하여 환자의 코에 분사하였다. 환 자는 평상시 호흡할 때와 같은 속도로 코를 통해 공기를 흡 입하고 입을 통해 숨을 내쉬도록 교육하였다. 6 분간 총 400 liter의 저온저습공기를 사용하여 유발검사를 시행하였으며, 환자가 심한 과호흡 증상 등의 부작용을 보이면 즉각 검사를 중단하도록 하였다.

저온저습공기 유발검사 전과 15 분 후, 시각아날로그척도 (Visual Analogue Scale)를 이용하여 코막힘, 콧물, 재채기, 가려움증 증상의 변화를 평가하였다. 증상의 변화량은 “(변화 량 $)=($ 유발검사 후 증상점수 $)-($ 유발검사 전 증상점수)'로 정의 하였다.

환자의 혈청을 채취하였으며, 또한 유발검사 전후 비중격 에 거름종이를 1 분간 부착하여 비즙을 채취하였다. 거름종 이를 $4^{\circ} \mathrm{C}, 3000 \mathrm{rpm}$ 에서 15 분간 원심분리하여 비즙을 거름 종이로부터 분리해 내었다. 혈청 및 비즙 내 총 $\operatorname{IgE}$ 측정을 위해 Human Immunoglobulin IgE Single Plex Magnetic Bead Kit(Cat. HGAMMAG-303E; Merck Millipore, Darmstadt, Germany)를 사용하였으며, 제조사의 안내에 따라 실 험을 진행하였다.

\section{통계분석}

Group 간 비교를 위해 Kruskal-Wallis test 및 MannWhiney U test 등의 방법을 이용하였으며, 유발검사 전후 변화 의 유의성을 평가하기 위해 Wilcoxon Signed Rank test를 이 용하였다. $p$ value가 0.05 이하일 때 통계적 유의성이 있다고 판단하였다. 


\section{결 과}

Group $\mathrm{A}$ (대조군)에 비해 group $\mathrm{B}$ (알레르기 비염 환자군) 에서는 저온저습공기 유발검사 전후 코막힘, 콧물, 재채기,

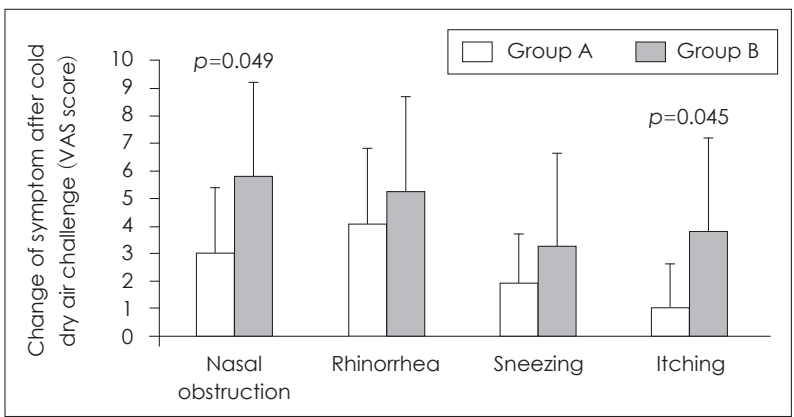

Fig. 1. Compare to those in group $A$ (control group), patients in group $B$ showed tendency of more aggravation of each nasal symptom. There was statistical significance in case of nasal obstruction and itching sense (for nasal obstruction, group a: $3.0 \pm 2.4$, group b: $5.8 \pm 3.4, p=0.049$; for itching, group a: $1.0 \pm 1.6$, group $B$ : $3.8 \pm 3.4, p=0.045$ ). Kruskal-Wallis and Mann-Whitney U tests. VAS: Visual Analogue Scale.

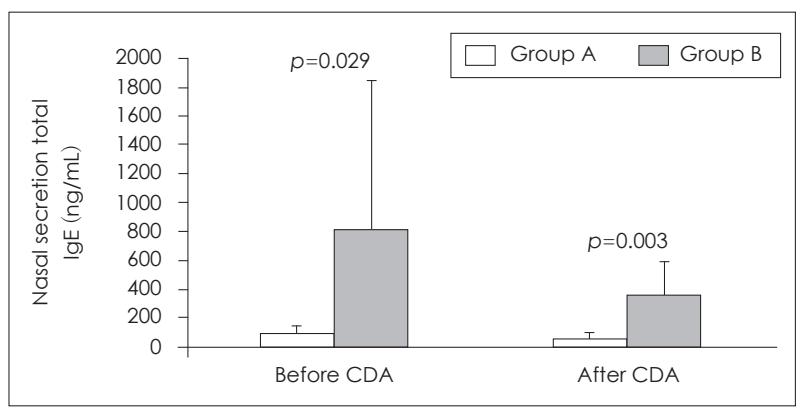

Fig. 2. Compare to those in group $A$ (control group), patients in group $B$ had higher titer of nasal fluid $\operatorname{lgE}$, before and after cold dry air (CDA) provocation test (before CDA, group A: $91.7 \pm 52.6$ $\mathrm{ng} / \mathrm{mL}$, group B: $810.0 \pm 1042.3 \mathrm{ng} / \mathrm{mL}, p=0.029$, after CDA, group A: $55.8 \pm 43.8 \mathrm{ng} / \mathrm{mL}$, group B: $354.9 \pm 236.7 \mathrm{ng} / \mathrm{mL}, p=0.003)$. Kruskal-Wallis and Mann-Whitney $U$ tests.
가려움증 등 각종 비강 증상의 변화량이 더욱 큰 경향을 보였 으며, 코막힘(group A: 3.0 \pm 2.4 , group B: $5.8 \pm 3.4, p=0.049$ ) 및 가려움증(group $\mathrm{A}: 1.0 \pm 1.6$, group B: $3.8 \pm 3.4, p=0.045$ ) 증상의 경우 통계적으로 유의미한 차이를 보였다(Fig. 1).

Group A(152.7 $\pm 67.3 \mathrm{ng} / \mathrm{mL})$ 에 비해 group B(612.1 \pm 291.4 $\mathrm{ng} / \mathrm{mL}$ )에서 통계적으로 유의하게 혈청 내 총 $\mathrm{IgE}$ 수치가 높 았다 $(p=0.001)$. 또한 group $\mathrm{A}$ 에 비해 group $\mathrm{B}$ 에서, 저온저습 공기 유발검사 시행 전(group A: 91.7 $\pm 52.6 \mathrm{ng} / \mathrm{mL}$, group B: $810.0 \pm 1042.3 \mathrm{ng} / \mathrm{mL}, p=0.029)$ 및 시행 후(group A: 55.8土 $43.8 \mathrm{ng} / \mathrm{mL}$, group B: $354.9 \pm 236.7 \mathrm{ng} / \mathrm{mL}, p=0.003)$ 통계 적으로 유의하게 비즙 내 총 $\mathrm{IgE}$ 의 수치가 높았다(Fig. 2). 같 은 그룹 내에서 저온저습공기 유발 전후를 각각 비교하였을 때, group $\mathrm{A}$ 와 $\mathrm{B}$ 에서 모두 감소하는 경향을 보였으나 통계적 으로 유의하지는 않았다 $(p>0.05)$.

선형회귀분석법에 의해 혈청 내 총 $\mathrm{IgE}$ 와 저온저습공기 유발검사 시행 전 비즙 내 총 $\operatorname{IgE}$ 농도, 그리고 유발검사 시행 후 비즙 내 총 $\operatorname{IgE}$ 농도 간의 상관관계를 분석한 결과, 유발 검사 시행 후 비즙 내 총 $\operatorname{IgE}$ 농도가 혈청 내 총 $\operatorname{IgE}$ 농도와 보 다 강한 상관관계를 갖는 것을 알 수 있었다 $\left(\mathrm{R}^{2}=0.749\right)(p<$ 0.001)(Fig. 3).

\section{고 찰}

저온저습공기 유발검사 전후 각종 코 증상의 변화량을 측 정하였을 때, 알레르기 비염 환자에서 대조군 환자에 비해 큰 변화를 보이는 경향이 있었으며, 코막힘 및 가려움증 증 상의 경우 통계적으로 유의한 차이가 있음을 확인하였다. 그 러나, 이러한 코 증상 증가의 기전이 전신적 알레르기 감작과 관련되어 있을 가능성은 다소 적을 것으로 여겨진다. 이전의
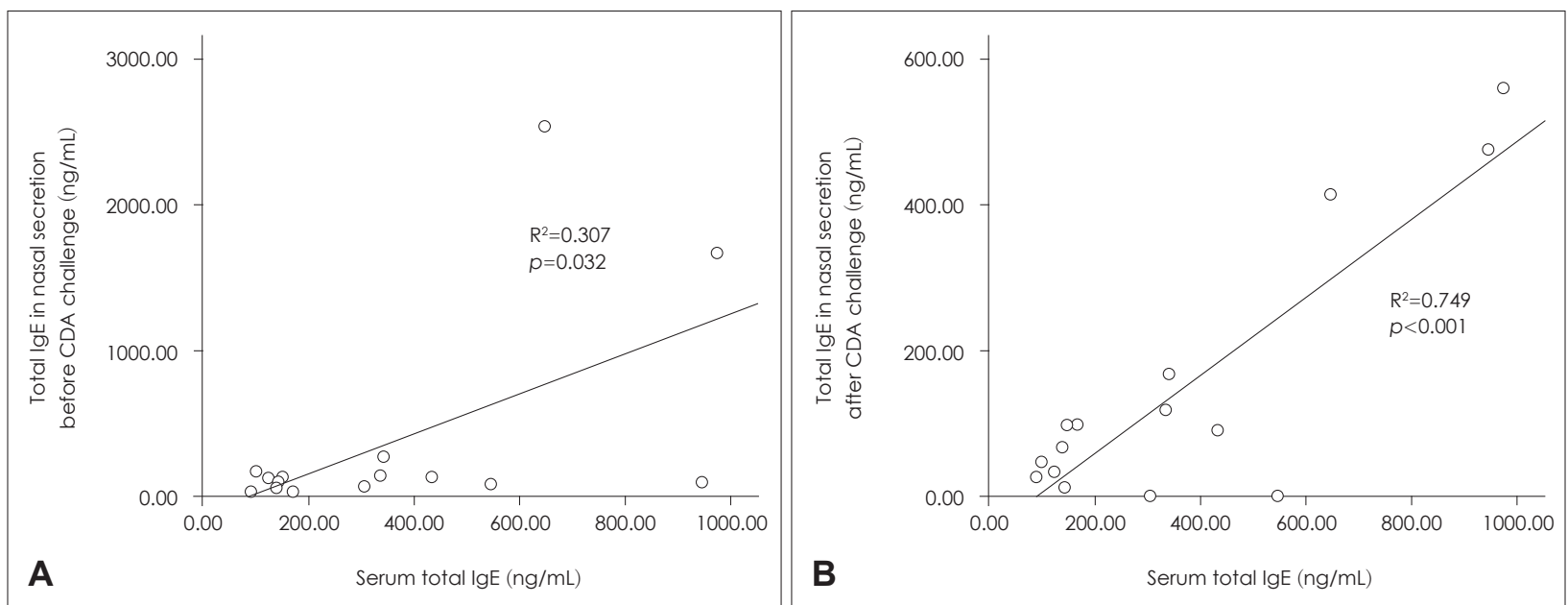

Fig. 3. Correlation between serum total $\lg E$ and $(A)$ nasal fluid $\lg E$ before cold dry air (CDA) provocation and (B) nasal fluid lgE after CDA provocation. Linear correlation analysis. 
연구 결과를 보면, 건강 자원자군과 알레르기 비염 환자군에 대하여 각각 저온저습공기 유발검사를 시행한 이후 코 증상 변화량을 비교하였을 때 유의미한 차이가 관찰되지 않았다. ${ }^{4}$ 그러나, 환자들을 알레르기 감작 여부와 무관하게 주관적인 비특이적 과반응성 여부에 따라 분류하였을 때, 비특이적 과 반응성이 있는 환자가 그렇지 않은 환자에 비해 저온저습공 기 유발검사 전후 증상이 매우 유의하게 증가함이 보고되었 다. 따라서, 특정 알레르기 항원에 대한 비강 내의 반응을 평 가하고 싶을 때에는 항원 추출물을 이용한 비강유발검사를 시행하는 것이 유용하고, 알레르기 여부와 상관없이 비특이 적 자극에 대한 비강의 과반응성을 평가하고 싶을 때에는 저온저습공기 유발검사가 도움이 된다.) 따라서 본 연구에서 알레르기 비염 환자군의 증상 변화량이 크게 나타난 것은, 비 특이적 과반응성을 가진 환자군이 좀 더 많이 포함되었기 때 문으로 해석할 수 있다. 대조군 및 환자군을 대상으로, 연구 수행 전 비강유발검사를 시행함으로써 생리식염수 등에 대 한 비특이적 과반응성을 평가함으로써, 각각의 그룹에서 비 특이적 과반응성을 가진 환자의 비율을 조사하였다면 보다 유의한 결과를 얻을 수 있었을 것으로 생각된다.

저온저습공기 유발검사에 대한 이전의 연구들에서는 주로 유발 전후 증상의 변화량을 평가하거나, 비강통기도검사 (rhinometry) 등을 이용하여 비강의 저항 변화를 측정한 연 구들이 많았다. ${ }^{3,89}$ 저온저습공기 자극에 의해 비만세포로부 터 분비되는 histamine, prostaglandin D2, tryptase 등의 매개물질 및 lysozyme, albumin 등이 증가한다는 보고는 있 었으나, ${ }^{10,11)}$ 비즙 내 면역글로불린 $\mathrm{E}$ 의 변화를 측정한 연구는 본 연구가 최초이다. 저온저습공기 자극 전과 후 대조군과 알레르기 비염 환자군을 비교하였을 때, 알레르기 비염 환자 군에서 통계적으로 유의미하게 비즙 내 면역글로불린 $\mathrm{E}$ 의 농도가 높은 것으로 알 수 있었다. 그러나 저온저습공기 자 극 전과 후를 비교하였을 때에는, 두 그룹에서 모두 비록 통 계적으로 유의하지는 않았으나 자극 전에 비하여 자극 후에 면역글로불린 $\mathrm{E}$ 의 농도가 오히려 감소하는 경향을 보였다. 따라서, 저온저습공기 유발검사에 따른 코 증상의 변화는 면 역글로불린 $\mathrm{E}$ 의 증가와는 관련성이 적을 것으로 여겨진다. 저온저습공기 유발검사의 기전은, 부교감신경계 활성화와 연 관이 있다는 연구 결과가 있다. ${ }^{12}$ 부교감신경계 활성화에 따 라 비강 내 분비샘으로부터 비즙의 분비가 증가하고 비강 내 수용혈관이 팽창함으로써 코막힘, 콧물 등의 증상을 유발할 수 있으며, 실제로 본 연구진의 선행연구에서도 비특이적 과 반응성이 있는 환자군에서 비즙의 양이 증가하는 것을 알 수 있었다.) 따라서, 부교감신경계 활성화에 따라 비즙의 양 자체가 증가함으로써 희석 효과에 의해 면역글로불린 $\mathrm{E}$ 농
도가 낮아졌을 것으로 생각된다.

혈청 내 면역글로불린 $\mathrm{E}$ 와 저온저습공기 유발전 비즙 내 $\operatorname{IgE}$ 농도 사이의 상관관계를 분석하였을 때 유의미하지만 다 소 약한 상관관계가 관찰되었다. 반면, 혈청 내 면역글로불린 $\mathrm{E}$ 와 저온저습공기 유발후 비즙 내 $\mathrm{IgE}$ 농도 사이의 상관관계 를 분석하였을 때에는 통계적으로 매우 유의미하며, 강한 상 관관계가 관찰되었다 $\left(\mathrm{R}^{2}=0.749\right)$. 비강 내 저온저습공기 자극 으로 인해 부교감신경계가 활성화되면서, 부교감신경계 활성 화에 따라 비즙의 양이 증가할 뿐 아니라, 특히 group B의 경 우 비특이적 과반응성에 의해 면역글로불린 $\mathrm{E}$ 분비 역시 증 가하기 때문에 이러한 현상이 나타나지 않을까 추측해 볼 수 있다. 이를 평가하기 위하여, 보다 많은 수의 환자를 대상으로 하여 저온저습공기 자극 전후 비즙의 양 자체를 정량적으로 평가하는 등의 방법을 사용할 수 있을 것이다.

이전의 연구들에서, 본 연구진은 저온저습공기 유발검사 전후 음향비강통기도검사를 사용하여 총비강부피(total nasal volume), 비강 내 최소단면적(minimal cross-sectional area) 등의 변화를 함께 평가하여 왔다. ${ }^{4-7,13)}$ 그러나 본 연구에서는, 저온저습공기 유발 직후 비즙을 채취하기 위해 비중격에 거 름종이를 부착하였다. 이러한 처치 자체가 비강 내에 자극으 로 작용하여 영향을 미칠 수 있기 때문에, 본 연구에서는 음향 비강통기도검사를 시행하지 않고 단지 증상의 변화량만을 측정하였다. 또한 준비 및 유발검사, 비즙 채취 등의 전체 연 구에 소요되는 시간이 30 40분 정도로 진료 중 많은 수의 환자를 등록하는 데 다소 어려움이 있어, 소규모의 환자군을 대상으로 한 것이 본 연구의 단점 중 하나이다.

비즙을 채취하기 위해서는 생리식염수를 이용한 세척법, 특 수 기구를 이용한 직접흡입법 및 거름종이 등을 이용한 방법 등이 있다. ${ }^{1-21)}$ 그러나 어떠한 방법을 이용하여도 모든 환자 에서 일정한 양의 충분한 비즙을 채취하는 데는 어려움이 있 어, 비즙을 이용한 연구가 어려운 실정이다. ${ }^{22-24)}$ 본 연구를 수 행하기에 앞서, 예비연구로서 세척법, 직접흡입법 및 거름종이 를 이용한 방법으로 각각 비즙을 채취하여 결과를 비교하여 보았다. 그 결과 세척법의 경우에는 생리식염수에 의한 희석 효과 때문에 정량적으로 비즙 내 면역매개물질의 농도를 분 석하기 어려웠고, 또한 직접흡입법의 경우에는 환자에 따른 편차가 심하여 비즙을 전혀 채취할 수 없는 경우도 많았다. 또한 세척이나 직접흡입 역시 비강 점막에 대하여 자극 증상 이 발생하므로, 본 연구에서는 거름종이를 이용한 흡입법을 사용하기로 하였다. 그럼에도 불구하고 본 연구에서도 비즙의 양이 많지 않아, 면역글로불린 $\mathrm{E}$ 이외의 다른 염증매개물질 을 분석하지 못하였다. 또한 비즙 내에 포함되어 있는 염증매 개물질들은 농도가 낮아, 일반적인 분석 키트의 탐지 역치 
(detection threshold) 내에 포함되지 않는 경우도 있으므로, 비즙 내 염증매개물질이 보다 정량적인 분석을 위해서는 보 다 민감도가 높은 분석 키트를 사용하여야 할 것이다.

결론적으로, 비특이적 과반응성을 갖는 알레르기 비염 환 자에서 저온저습공기 유발검사는 비강 내 증상 변화 및 비즙 내 면역글로불린 $\mathrm{E}$ 의 변화를 평가함으로써, 유용한 보조도 구로 활용될 수 있다.

\section{Acknowledgments}

This study was supported by Inha University Research Grant.

\section{REFERENCES}

1) Jacobs R, Lieberman P, Kent E, Silvey M, Locantore N, Philpot EE. Weather/temperature-sensitive vasomotor rhinitis may be refractory to intranasal corticosteroid treatment. Allergy Asthma Proc 2009; 30(2):120-7.

2) Lluch-Bernal M, Dordal MT, Antón E, Campo P, Colás C, Dávila I, et al. Nasal hyperreactivity: nonspecific nasal provocation tests. Review by the rhinoconjunctivitis committee of the spanish society of allergy and clinical immunology. J Investig Allergol Clin Immunol 2015;25(6):396-407.

3) Braat JP, Mulder PG, Fokkens WJ, van Wijk RG, Rijntjes E. Intranasal cold dry air is superior to histamine challenge in determining the presence and degree of nasal hyperreactivity in nonallergic noninfectious perennial rhinitis. Am J Respir Crit Care Med 1998; 157(6 Pt 1):1748-55.

4) Kim YH, Oh YS, Kim KJ, Jang TY. Use of cold dry air provocation with acoustic rhinometry in detecting nonspecific nasal hyperreactivity. Am J Rhinol Allergy 2010;24(4):260-2.

5) Kim YH, Jang TY. Diagnostic criteria of nonspecific hyperreactivity using cold dry air provocation with acoustic rhinometry. Otolaryngol Head Neck Surg 2011;144(1):91-5.

6) Kim YH, Jang TY. Usefulness of the subjective cold hyperresponsiveness scale as evaluated by cold dry air provocation. Am J Rhinol Allergy 2012;26(1):45-8.

7) Kim YH, Jang TY. Nasal provocation test using allergen extract versus cold dry air provocation test: which and when? Am J Rhinol Allergy 2013;27(2):113-7.

8) Shusterman DJ, Tilles SA. Nasal physiological reactivity of subjects with nonallergic rhinitis to cold air provocation: a pilot comparison of subgroups. Am J Rhinol Allergy 2009;23(5):475-9.

9) Van Gerven L, Boeckxstaens G, Jorissen M, Fokkens W, Hellings PW. Short-time cold dry air exposure: a useful diagnostic tool for nasal hyperresponsiveness. Laryngoscope 2012;122(12):2615-20.

10) Togias AG, Naclerio RM, Proud D, Fish JE, Adkinson NF Jr, KageySobotka A, et al. Nasal challenge with cold, dry air results in release of inflammatory mediators. Possible mast cell involvement. J Clin
Invest 1985;76(4):1375-81.

11) Proud D, Bailey GS, Naclerio RM, Reynolds CJ, Cruz AA, Eggleston PA, et al. Tryptase and histamine as markers to evaluate mast cell activation during the responses to nasal challenge with allergen, cold, dry air, and hyperosmolar solutions. J Allergy Clin Immunol 1992;89(6):1098-110.

12) Philip G, Jankowski R, Baroody FM, Naclerio RM, Togias AG. Reflex activation of nasal secretion by unilateral inhalation of cold dry air. Am Rev Respir Dis 1993;148(6 Pt 1):1616-22.

13) Kim YH, Jang TY. Subjective cold hyper-responsiveness grade reflects age- and duration-related increase of nonspecific nasal hyperreactivity. Auris Nasus Larynx 2013;40(2):184-8.

14) Wang DY, Clement P. Pathogenic mechanisms underlying the clinical symptoms of allergic rhinitis. Am J Rhinol 2000;14(5):325-33.

15) Yamazaki M, Kimura K, Watanabe S, Komiyama O, Mishiku Y, Yamamoto $\mathrm{K}$, et al. [Use of a rapid detection assay for influenza virus, on nasal aspirate specimens]. Kansenshogaku Zasshi 1999;73(10): 1064-8.

16) Besançon-Watelet C, Béné MC, Montagne P, Faure GC, Jankowski R. Eosinophilia and cell activation mediators in nasal secretions. Laryngoscope 2002;112(1):43-6.

17) Niehaus MD, Gwaltney JM Jr, Hendley JO, Newman MJ, Heymann PW, Rakes GP, et al. Lactoferrin and eosinophilic cationic protein in nasal secretions of patients with experimental rhinovirus colds, natural colds, and presumed acute community-acquired bacterial sinusitis. J Clin Microbiol 2000;38(8):3100-2.

18) Kim SS, Kim KS, Lee JG, Park IY, Koo JS, Yoon JH. Levels of intracellular protein and messenger RNA of mucin and lysozyme in normal human nasal and polyp epithelium. Laryngoscope 2000; 110(2 Pt 1):276-80.

19) Ingels K, Durdurez JP, Cuvelier $C$, van Cauwenberge P. Nasal biopsy is superior to nasal smear for finding eosinophils in nonallergic rhinitis. Allergy 1997;52(3):338-41.

20) Gevaert $P$, Lang-Loidolt $D$, Lackner A, Stammberger H, Staudinger H, Van Zele T, et al. Nasal IL-5 levels determine the response to antiIL-5 treatment in patients with nasal polyps. J Allergy Clin Immunol 2006;118(5):1133-41.

21) Klimek L, Reske-Kunz AB, Malling HJ. [Methods for monitoring of therapeutic efficacy in immunotherapy of allergic rhinitis]. Wien Med Wochenschr 1999;149(14-15):394-402.

22) Kim YH, Jang TY, Kim JE, Lim DW, Kim KS. Comparison of collecting methods of nasal fluids using albumin after nasal provocation in allergic patients. Korean J Otorhinolaryngol-Head Neck Surg 2010;53(10):615-9.

23) Kim JK, Sung YW, Jang HJ, Lim CH, Shim DB, Shin HA. The effect of allergen provocation on the nasal cycle. Korean J OtorhinolaryngolHead Neck Surg 2004;47(12):1261-66.

24) Shin SY, Cho JS, Jin YW, Lee KH, Moon JH, Cha CI. Result of allergic skin test, MAST and nasal provocation test in children with atopic dermatitis. Korean J Otorhinolaryngol-Head Neck Surg 2001; 44(5):499-505. 